\title{
ANALYSIS OF POTENTIAL ENERGY AND ENVIRONMENTAL IMPACT FROM COAL GASIFICATION THROUGH SIMULATION OF PLASMA GASIFICATION PROCESS OF INDONESIAN LOW-RANK COAL
}

\author{
ANALISIS POTENSI ENERGI DAN DAMPAK LINGKUNGAN \\ GASIFIKASI BATUBARA MELALUI SIMULASI PROSES GASIFIKASI \\ PLASMA BATUBARA INDONESIA KUALITAS RENDAH
}

\author{
PRIYO A. SESOTYO ${ }^{1 *}$, MUHAMMAD NUR ${ }^{2,3}$ and OKI MURAZA ${ }^{4}$ \\ ${ }^{1}$ Department of Electrical Engineering, Faculty of Engineering, Semarang University, Indonesia \\ ${ }^{2}$ Center of Plasma Research, Diponegoro University, Semarang, Indonesia \\ ${ }^{3}$ Department of Physics, Faculty of Science \& Mathematics, Diponegoro University, Indonesia \\ ${ }^{4}$ Research \& Technology Innovation, PT Pertamina (Persero), Indonesia \\ ${ }^{*}$ Corresponding e-mail: psesotyo@usm.ac.id
}

\begin{abstract}
Indonesia's coal reserve is abundant with its lower price and widely distributed than oil and natural gas. However, the coal emits high carbon dioxide gas $\left(\mathrm{CO}_{2}\right)$ and sulfur compounds $\left(\mathrm{H}_{2} \mathrm{~S}, \mathrm{SO} \times\right)$ to the environment during utilization. Plasma gasification can overcome those lacks using the external electric energy through a plasma torch. The chemical properties of coal have impacts on the energy content and environmental benchmarking. Using steam as a gasifying agent should be adequate to produce $\mathrm{H}_{2}$ and $\mathrm{CO}$ syngas. A research has been carried out to analyze and understand the benefit of using different gasifying agent for maximizing the $\mathrm{H}_{2}$ production and minimizing the environmental impact. Pure Steam (PS) gasifying agent to coal ratio of 0.4 has shown $43.76 \% \mathrm{H}_{2}$ composition in syngas and cold gasification efficiency (CGE) with $37.71 \%$. The PS to coal ratio of 0.2 has a significant carbon conversion efficiency of $4.75 \%$ and the PS to coal ratio of 0.6 has a gross energy potential of $86.5 \mathrm{~kW}$. Using such the PS is significantly better than the mixture of steam oxygen (SO) as the gasifying agent since it needs to have a greater SO flow rate to have the SO to coal ratio of 1.00 .
\end{abstract}

Keywords: plasma gasification, environmental impact; low-rank coal; syngas; energy potential.

\begin{abstract}
ABSTRAK
Cadangan batubara Indonesia sangat melimpah dengan harga yang lebih murah dan tersebar lebih luas dibandingkan dengan minyak dan gas alam, sayangnya batubara mengeluarkan gas karbon dioksida $\left(\mathrm{CO}_{2}\right)$ dan gas senyawa belerang $\left(\mathrm{H}_{2} \mathrm{~S}\right.$, SOx) tinggi ke lingkungan saat digunakan. Gasifikasi plasma dapat mengatasi kekurangan tersebut menggunakan energi listrik eksternal melalui obor plasma. Sifat kimiawi batubara berdampak pada kandungan energi dan tolok ukur lingkungan. Penggunaan uap sebagai agen gasifikasi harus cukup untuk menghasilkan syngas $\mathrm{H}_{2}$ dan $\mathrm{CO}$. Penelitian untuk menganalisis dan memahami manfaat penggunaan agen gasifikasi yang berbeda untuk memaksimalkan produksi hidrogen sekaligus meminimalkan dampak lingkungan telah dilakukan. Dengan rasio agen gasifikasi uap murni (PS) kepada batubara sebesar 0.4 telah menunjukkan komposisi $\mathrm{H}_{2}$ sebesar $43.76 \%$ pada syngas dan nilai efisiensi gasifikasi dingin (CGE) sebesar 37.71\%. Rasio PS terhadap batubara sebesar 0.2 menunjukkan nilai efisiensi konversi carbon sebesar 4.75\%. Rasio PS terhadap batubara sebesar 0.6 juga menunjukkan nilai kotor potensi energi sebesar $86.5 \mathrm{~kW}$. Penggunaan PS sebagai agen gasifikasi lebih baik daripada campuran uap dan oksigen (SO), karena dibutuhkan laju aliran SO lebih besar pada rasio SO terhadap batubara sebesar 1.00 .
\end{abstract}

Kata kunci: gasifikasi plasma, dampak lingkungan, batubara kualitas rendah, syngas, potensi energi. 


\section{INTRODUCTION}

Indonesia's coal reserve is abundant with its lower price and widely distributed than oil and natural gas. However, it emits high carbon dioxide gas $\left(\mathrm{CO}_{2}\right)$ and sulfur compounds $\left(\mathrm{H}_{2} \mathrm{~S}\right.$, $\left.\mathrm{SO}_{\mathrm{x}}\right)$ to the environment. Because of coal energy conversion pollution, there has been a growing interest in clean coal technology. Gasification means converting the solid into a gas. It is one of the clean energy technologies, which decomposes the coal as a solid by the thermal process, produces a syngas, and comprises hydrogen $\left(\mathrm{H}_{2}\right)$ and carbon monoxide (CO). There are 2 (two) available gasification methods, namely: conventional and plasma gasifications. The former relates to the older method that has flaws, such as high-pressure operating conditions, longer start-up periods to heat the environment, and unsuitable for low-rank coal. The later known as thermal plasma, is the newer method that can overcome those lacks. Figure 1 shows the various applications of plasma gasification. It features the plasma, since its high temperature and high reactivity, due to free ions and radicals, benefit plasma as the powerful medium for encouraging chemical reactions (Samal, 2017). Its operating conditions required atmospheric pressure, a shorter start-up period to escalate the required temperature, and external electric energy through a plasma torch. A plasma torch is a device that can reach high gasification reaction temperature using electrical energy with the proper current and voltage values. Plasma is a physical state of matter with high electrical conductivity with gaseous properties (Samal, 2017). Within high temperatures, oxidation occasionally happens, resulting in minimal $\mathrm{CO}_{2}$ generation. Aside from its advantages, there are some disadvantages: abundant energy consumption and the sophisticated requirement of the process equipment to withstand the high temperature. Besides its advantages and disadvantages, thermal plasma technology has some limitations, such as very short raw material residence time in the high-temperature zone, of 0.1 to 10 . Waste heat recovery technology is needed for a syngas because of their moderate heat loss and the decomposition material in the reactor is slower than that of the gasifying agent reaction in the torch (Samal, 2017).

There is a particular type of coal reserve in Indonesia, low-rank and high-rank.
Significant volumes of water and ash lead to the low-rank coals has lower calorific value, and high-rank coal has less water content and ash. Indonesian low-rank coal (brown coal) has a calorific value less than 5,700 $\mathrm{kcal} / \mathrm{kg}(24 \mathrm{MJ} / \mathrm{kg})$ (moist, ash-free basis) (United Nation, 2018) and a high-rank, having a calorific value greater than $5,700 \mathrm{kcal} / \mathrm{kg}$. The percentage of low-rank coal coverage is $88 \%$, while high-rank coal coverage is only $12 \%$, and their locations are over South Sumatra, South Kalimantan, and East Kalimantan province (Sihite, 2012). The lowrank coal is much more reactive than the high-rank coal because of the high content of reactive sites, such as chemisorbed oxygen in the coal matrix from low-rank coal (Mishra, Gautam and Sharma, 2018). The government has already started a plan to establish a clean coal technology to utilize the low-rank coal with less environmental impact and economically that can be used in the diverse industry by gasification technology since 2005 in the Research and Development Centre for Mineral and Coal Technology, Bandung (BLU tekMIRA, 2019). The chemical properties of coal have effects on the energy content and environmental benchmarking, which are often used as the basis of sale contacts. Those are low heating value (LHV) as of energy losses used to vaporize water, volatile matter (VM), inherent moisture (IM), sulfur (S), chlorine (Cl), and an ash content of coal and fuel ratio (FR) (Nursanto and Ilcham, 2018).

To maintain higher temperatures in the gasification reactor for the low-rank coal process, the plasma torch supplies additional heat (Yoon and Goo Lee, 2012). For plasma gasification technology, using steam as the gasifying agent, however, as a pure or as a mixture, should generate syngas containing $\mathrm{H}_{2}$ and $\mathrm{CO}$ (Sesotyo, Nur and Suseno, 2019). Partial oxidation happens by gasifying oxygen, and the calorific content of coal feedstock is low. The more oxygen provided, the less electric energy consumed for the thermal plasma generator (Georgiev and Mihailov, 1992). The use of oxygen from the oxygen generator as the mixture with steam for the gasifying agent can raise the gasification efficiency, but the mixing ratio should be kept as low as possible for the steam content since it can cause an increase in the moisture of the syngas (Sesotyo, Nur and Suseno, 2019). 


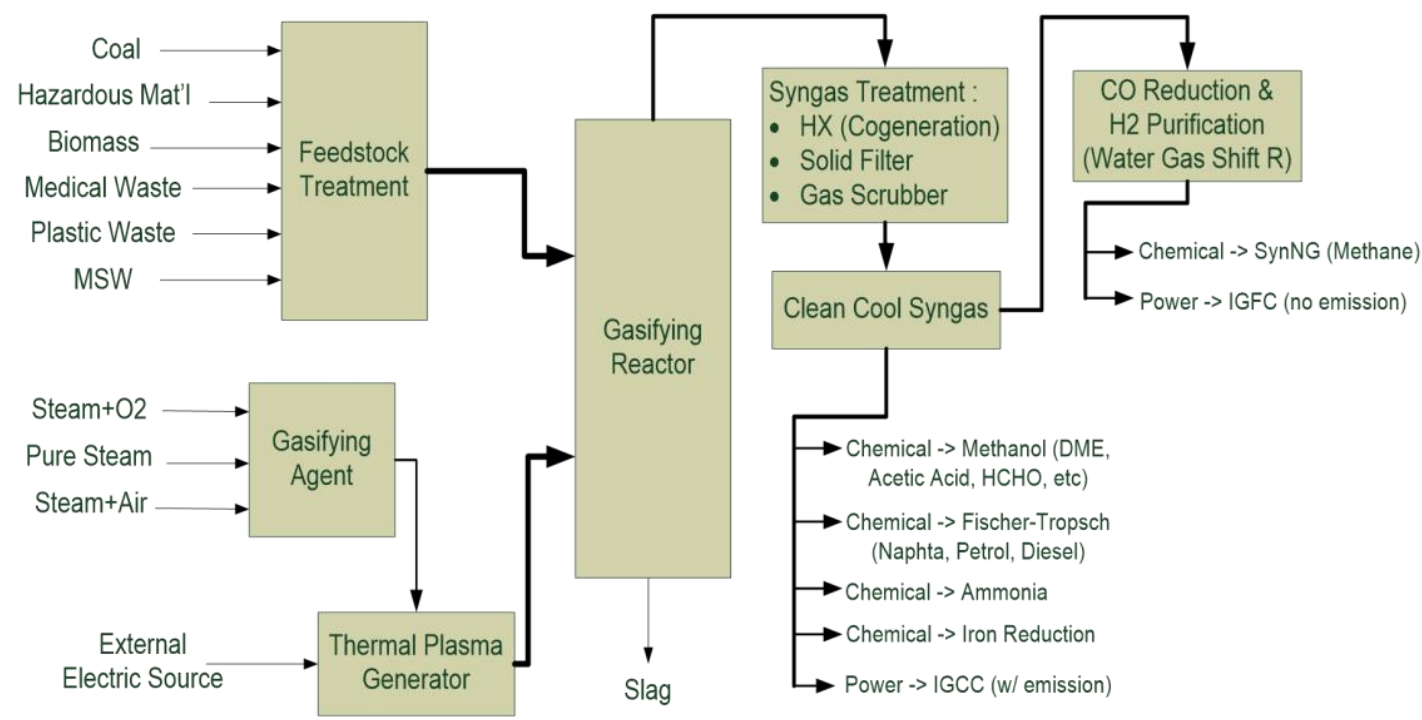

Figure 1. Alternate plant configuration for various applications of plasma gasification (Pourali, 2010; Tobergte and Curtis, 2013; Enersol Technologies, 2019; Sesotyo, Nur and Suseno, 2019)

Coal gasification thermodynamic analysis in the formation of syngas involves the equilibrium reaction. The syngas mainly consists of hydrogen and carbon monoxide. The syngas composition depends on the source of coal, coal flow rate, gasifying agent flow rate, type and composition of the gasifying agent, and energy consumed (Sesotyo, Nur and Muraza, 2020).

In this study, the low-rank coal gasification characteristics subjected to the plasma torch and referring to coals and operating conditions properties, were studied. Therefore, the changes in the composition of the supplied gasifying agent (steam, oxygen, and a mixture of steam and oxygen), characteristics of the syngas composition, energy potential, temperature distribution, overall efficiency, and greenhouse gases (GHG) emission were investigated. This study aims to better understand the benefit of using a certain gasifying agent of plasma gasification, considering the economic coal rate consumption for a better new energy method of coal gasification.

\section{METHOD}

This section describes the research method that is used in conducting this study.

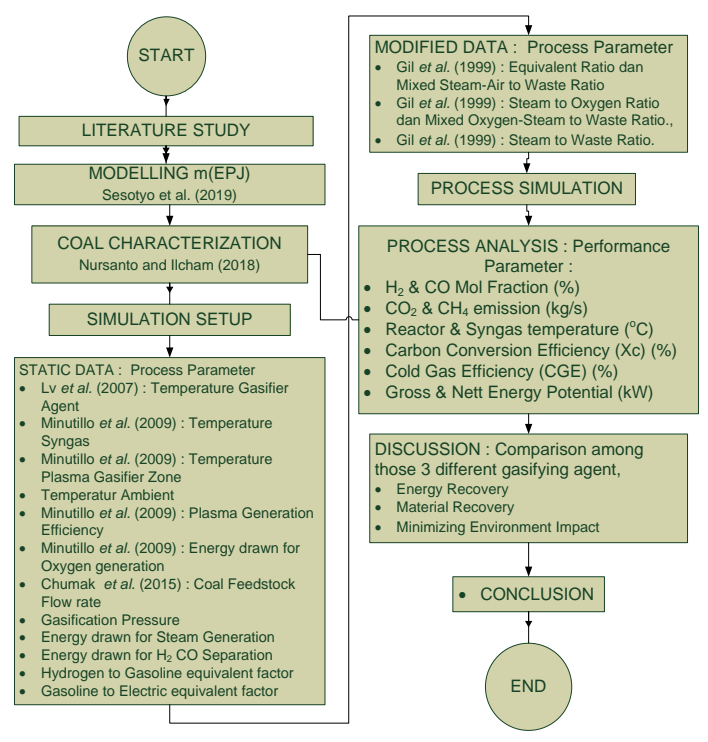

Figure 2. Research method of plasma gasification modeling

\section{Coal Characterization}

The sample is taken from Warukin formation, South Kalimantan. The calorific value, proximate analysis, and ultimate analysis data of the lignite coal refers to Wara 120. Table 1 shows the calorific values in high heating value (HHV) and low heating value (LHV), proximate and ultimate values of coal used in this study. 
According to the research by Sesotyo, Nur and Muraza (2020), it was found out that the lignite coal possesses more energy potential rather than the sub-bituminous coal.

Table 1. Calorific, proximate and ultimate values of coals (Nursanto and Ilcham, 2018)

\begin{tabular}{ccc}
\hline Parameter & Unit & Wara 120 \\
\hline High heating value & $\mathrm{MJ} / \mathrm{kg}, \mathrm{db}$ & 31.59 \\
Low heating value & $\mathrm{MJ} / \mathrm{kg}, \mathrm{db}$ & 29.31 \\
Inherent Moisture & wt.\%, adb & 30.90 \\
Fixed Carbon & wt.\%. db & 28.94 \\
Volatile Matter & wt.\%. db & 64.95 \\
Ash & wt.\%. db & 6.11 \\
Carbon & wt.\%. db & 61.52 \\
Hydrogen & wt.\%. db & 6.24 \\
Nitrogen & wt.\%. db & 0.68 \\
Oxygen & wt.\%. db & 25.45 \\
\hline
\end{tabular}

Note: adb: air-dried basis $\quad \mathrm{db}$ : dry basis

\section{Simulation Setup of Plasma Gasification}

The plasma gasification process models were built using the process simulator software of ASPEN PLUS. This model results from the customized, modified EquiPlasmaJet (mEPJ) model, with the coal properties as in Table 1 to be key-in in the properties and input of process simulation block. mEPJ model, firstly developed by
Minutillo, Perna and Di Bona (2009) EPJ, with a little modification by introducing RStoic for the chemical stoichiometric approach to determine the syngas compound compositions, was second developed by Sesotyo (Sesotyo, Nur and Suseno, 2019). The different stages involved in the ASPEN PLUS simulation show the overall plasma gasification process. The plasma gasification device consists of six main parts: dryer, plasma generator, updraft gasifier hightemperature section, updraft gasifier lower temperature section, water separator, and mixer, as found in Figure 3.

Table 2 shows the process parameter primary assumption. Table 3 shows the boundary conditions, such as the decomposing calculator and chemical stoichiometry. Those conditions work inside the simulator to gain a thermochemicalequilibrium reaction to the plasma gasification process modeling.

Figure 3 shows the Modified EquiPlasmaJet (mEPJ) using PS as the gasifying agent with the variation of coal feedstock: Wara 120 (Lignite). Figure 4 shows the Modified EquiPlasmaJet (mEPJ) using a $\mathrm{SO}$ as the gasifying agent with the type of coal feedstock: Wara 120 (Lignite).

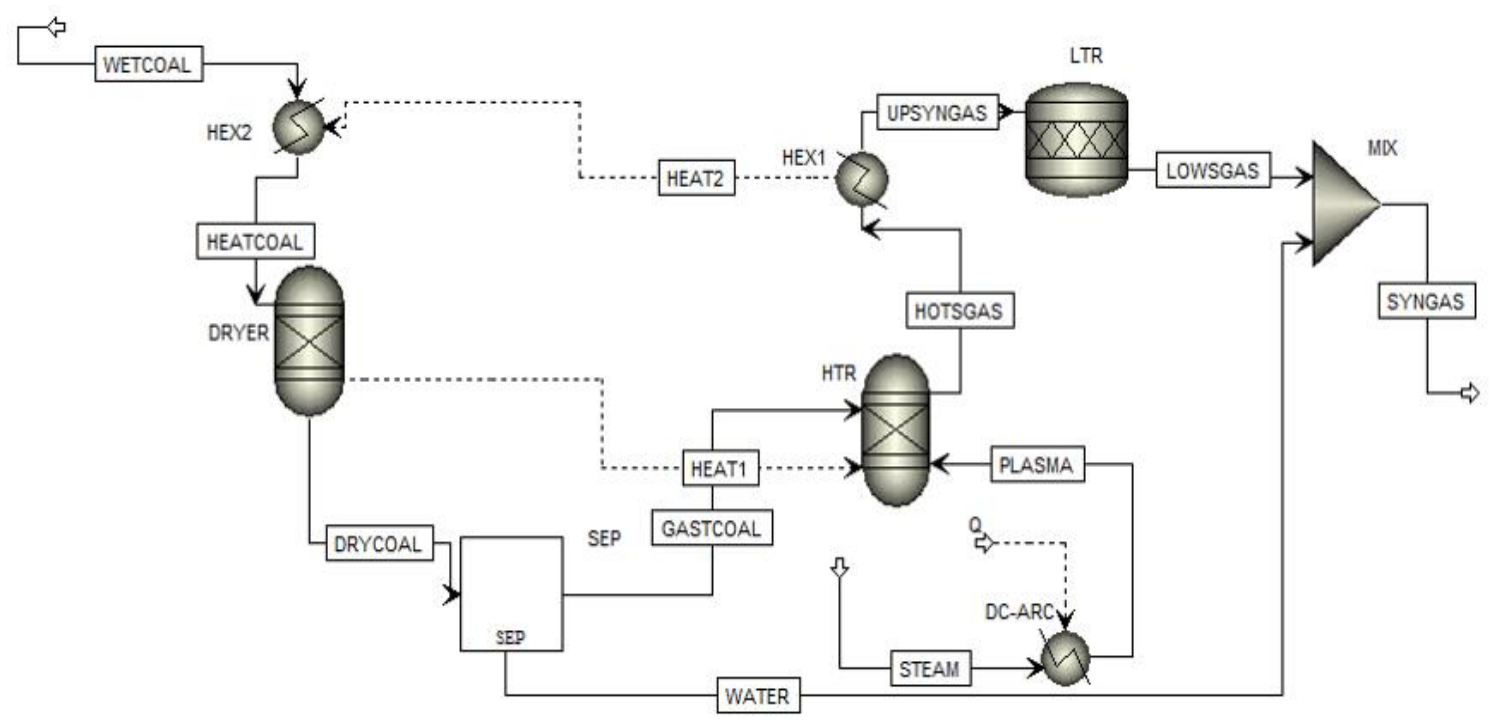

Figure 3. Gasification process model mEPJ with gasifying agent PS 
Table 2. Assumptions for the simulation

\begin{tabular}{lll}
\hline \multicolumn{1}{c}{ Variable } & Unit & \multicolumn{1}{c}{ Value } \\
\hline Gasification process pressure & atm & 1 \\
Thermal plasma temperature & ${ }^{\circ} \mathrm{C}$ & 4000 (Minutillo, Perna and Di Bona, 2009) \\
Steam gasifying agent temperature & ${ }^{\circ} \mathrm{C}$ & 200 (Nayak and Mewada, 2011) \\
Ambient temperature & ${ }^{\circ} \mathrm{C}$ & 25 \\
Coal mass flow rate & $\mathrm{Kg} / \mathrm{s}$ & $1.39 * 10^{-3}$ (Nayak and Mewada, 2011) \\
Steam to coal ratio & & $0.2 \sim 1.0$ (Yoon and Goo Lee, 2012) \\
Equivalent ratio & & $0.24 \sim 0.51$ (Gil et al., 1999) \\
Oxygen to coal ratio & & $0.2 \sim 1.0$ (Yoon and Goo Lee, 2012) \\
Mixed steam \& oxygen to coal ratio & & $0.2 \sim 1.0$ (Yoon and Goo Lee, 2012) \\
Energy for steam generation & $\mathrm{MWs}$ & 4.27 per 1 kg/s (Sesotyo, Nur and Suseno, 2019) \\
Energy for H2-CO separation process & $\mathrm{kWh} / \mathrm{ton}$ & 600 (Air Liquide, 2017) \\
Plasma generation efficiency & $\%$ & 90 (Minutillo, Perna and Di Bona, 2009) \\
\hline
\end{tabular}

Table 3. Boundary conditions for the simulation

- Steady-State Process Simulation

- The isobaric and adiabatic process state occurs inside the gasification reactor. Aspen Plus' HCoalgen and DCoalligt property models were used to project nonconventional enthalpy formation and specific heat in stable process pressure and density based on the proximate and ultimate analysis.

- The coal devolatilization duration time is instantaneous.

- The chemistry element and compounds used are: $\mathrm{H}_{2}, \mathrm{O}_{2}, \mathrm{CO}, \mathrm{CO}_{2}, \mathrm{CH}_{4}$, and $\mathrm{H}_{2} \mathrm{O}$.

- Char is considered a non-volatile solid and contains carbon and ash.

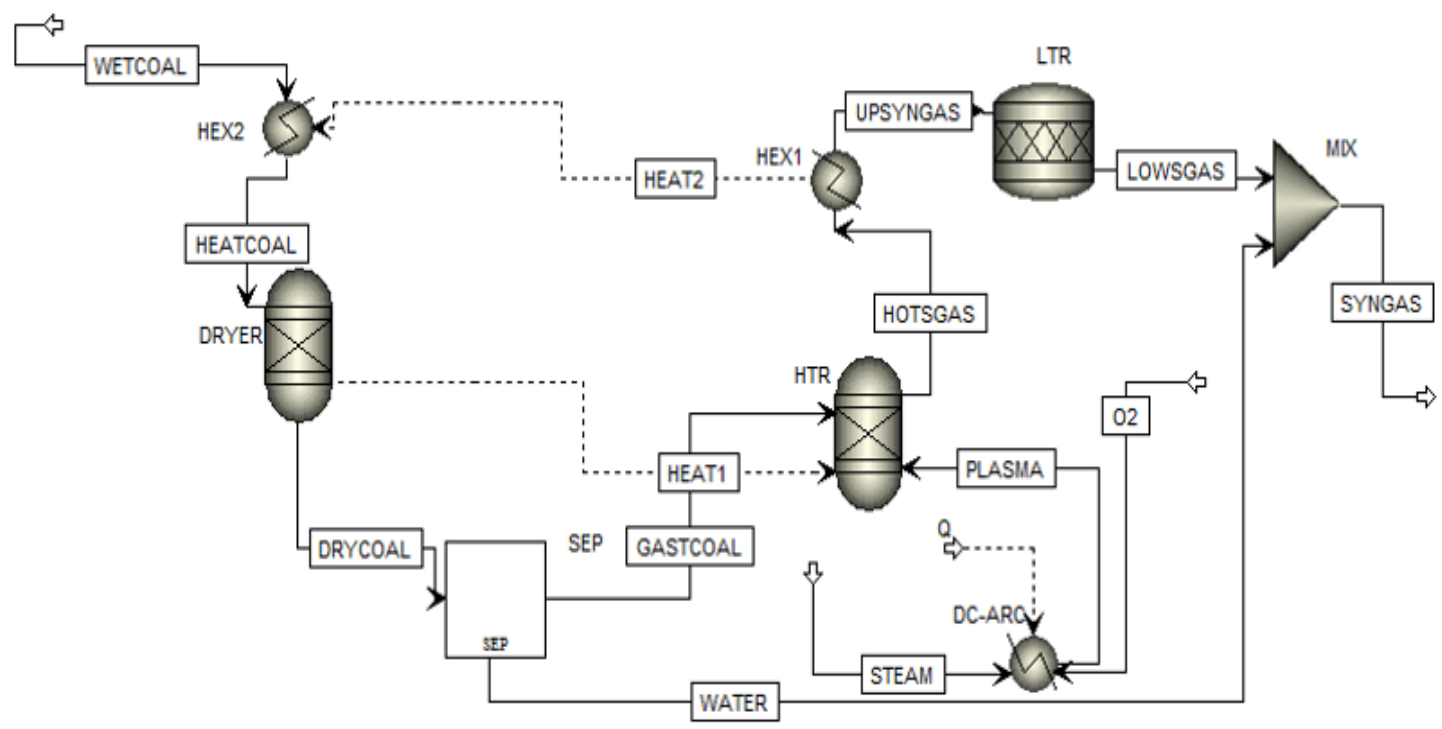

Figure 4. Gasification process model mEPJ with gasifying agent SO

As the temperature inside the reactor varies from top to bottom, the temperature was separated into two reaction zones to simplify the model. Two reaction zones represent the high-temperature reactor (HTR) and lowtemperature (LTR). The balanced composition is accomplished within the HTR by directly reducing Gibbs free energy for a given range of gas products without the predicted thermochemical reaction. Within the LTR, in a non-stoichiometric reaction, the equilibrium composition is obtained by a low-temperature setting. Table 4 shows a short description of the block used. Since only the coal's organic element is decomposed, the mEPJ model abandons the inorganic element. 


\section{Coal Decomposition}

The ASPEN PLUS yield reactor, RYield, was used to simulate the decomposition of the feed. In this step, coal was altered into its essential components, including $\mathrm{C}, \mathrm{H}, \mathrm{O}, \mathrm{S}$, $\mathrm{N}$, and ash, by determining the yield distribution according to the ultimate analysis (Nikoo and Mahinpey, 2008).

Table 4. Process block diagram of Modified EquiPlasmaJet (Sesotyo, Nur and Suseno, 2019)

\begin{tabular}{|c|c|c|}
\hline $\begin{array}{l}\text { Block } \\
\text { name }\end{array}$ & $\begin{array}{l}\text { Block } \\
\text { Type }\end{array}$ & Description \\
\hline Dryer & RYield & $\begin{array}{l}\text { Non-Stoichiometric } \\
\text { reactor on accepted yield } \\
\text { element distribution }\end{array}$ \\
\hline HTR & RGibbs & $\begin{array}{l}\text { Accurate hydrate reactor } \\
\text { and multiphase } \\
\text { equilibrium on Gibbs free } \\
\text { energy minimization }\end{array}$ \\
\hline LTR & RStoic & $\begin{array}{l}\text { Stoichiometric reactor with } \\
\text { accepted chemical } \\
\text { reaction }\end{array}$ \\
\hline $\begin{array}{l}\text { HEX1 \& } \\
\text { HEX2 }\end{array}$ & Heater & $\begin{array}{l}\text { Conventional } \\
\text { exchanger }\end{array}$ \\
\hline SEP & Separator & $\begin{array}{l}\text { Water separator from } \\
\text { feedstock }\end{array}$ \\
\hline $\begin{array}{l}\text { DC-ARC } \\
\text { MIX }\end{array}$ & $\begin{array}{l}\text { Heater } \\
\text { Mixer }\end{array}$ & $\begin{array}{l}\text { Thermal plasma generator } \\
\text { Gas Stream Mixer }\end{array}$ \\
\hline
\end{tabular}

\section{Volatile Reactions}

The ASPEN PLUS Gibbs reactor, RGibbs, was used for elusive combustion in obedience to the assumption that volatile reactions follow the Gibbs equilibrium. Coal consists of $\mathrm{C}, \mathrm{H}, \mathrm{N}, \mathrm{O}, \mathrm{S}, \mathrm{Cl}$, ash, and water content. Some carbon reacts with other atoms, becoming during the devolatilization process a gas compound form. The remaining forms of carbon take place in char gasification (Nikoo and Mahinpey, 2008).

\section{Char Gasification}

The ASPEN PLUS stoichiometric reactor, RStoic, is responsible for the char gasification process by determining the gasification reactions (Sudiro and Bertucco, 2009).

\section{Plasma Gasification Operation}

Several reaction processes occurred to convert the solid fuel into syngas. The fix-bed updraft gasifier reaction cycle consists of four stages, i.e., drying, pyrolysis, combustion, and char gasification. The combustion reaction was an exothermic mechanism that provides other exothermic energy (drying, pyrolysis, and char gasification section).

Moisture-containing coal (wet coal) was dried and evaporated to create dry coal at the drying point. The drying step is a quick process, considered complete when the temperature reaches $300^{\circ} \mathrm{C}$.

The next step is pyrolysis. Dry coal components were treated with the devolatilization reaction and yielded a solid products (char), condensable $\left(\mathrm{H}_{2} \mathrm{O}\right)$, and non-condensable gases $\left(\mathrm{CO}, \mathrm{CO}_{2}, \mathrm{H}_{2}\right.$, and $\mathrm{CH}_{4}$ ). Most of the coal weight was lost during pyrolysis and occurred rapidly during the initial stages as coal heats up. During this process, the labile chemical bonds between the aromatic coal branches were sundered, creating molecular weight fragments. Low molecular weight fragments were vaporized and disappeared from the particle of coal to constitute light, non-condensable, and char. Under standard devolatilization conditions, the fragments of high molecular weight and low vapour compound, condensable gas, remained in the coal until they were bound to the char lattice. The side product from the plasma gasification process was char, or in general, called slag. The chemical compositions of the slag, as the process residues, are different, as the various number of ash chemical compounds of the feed coals. Also, the different methods and operating conditions of the process are other factors of the slag's various chemical components. During the gasification process, non-volatile trace elements (including rare earth elements and yttrium (REY)) remain in the slag (Guo et al., 2021). REY is critical to modern society due to its excellent physicochemical industrial properties (Pagano et al., 2019).

The pyrolysis product then was reacted with air or $\mathrm{O}_{2}$-deficient, and in the combustion step, a partial oxidation reaction occurred. The amount of air was stoichiometric, and a partial oxidation reaction occurred with char, $\mathrm{H}_{2}$, and $\mathrm{CH}_{4}$. Partial combustion occurs in an oxygen-deficient atmosphere in a plasmagasification reactor. A gasification reactor requires roughly $30 \%$ to $50 \%$ of the theoretical oxygen content needed for full combustion to produce carbon dioxide and water. Carbon monoxide and hydrogen are 
the ideal materials, and only a portion of the carbon is fully oxidized to carbon dioxide. Partial combustion heat (exothermic) supplies the energy required to drive gasification reactions.

The last reaction was a gas-reduction reaction. A solid-gas reaction called the gasification phase was a crucial reaction to determine the flammable gas composition $\left(\mathrm{CO}, \mathrm{H}_{2}\right.$, and $\mathrm{CH}_{4}$ ) and low heating value (LHV). Reduced carbon, carbon dioxide, nitrogen, and water vapour, creating carbon monoxide, hydrogen, and methane. Oxygen was absorbed immediately in the combustion region, which required a small portion of the reactor section. Moreover, char conversion happened by much slower, reversible reactions with $\mathrm{CO}_{2}, \mathrm{H}_{2} \mathrm{O}$, and $\mathrm{H}_{2}$. The chemical reaction that occurs in the gasification is shown in Table 5.

\section{Simulation Procedure}

Once the simulation model is established, then prepare the simulation scenario according to each type of gasifying agent. In this study, there are 2 (two) gasifying agents: pure steam (PS) and mixture steam with oxygen (SO). There are 5 (five) different situations for each type of gasifier depending on the increment ratio of the gasifier's mass flow rate to coal flow rate, sort of $0.2,0.4,0.6$, 0.8 , and 1.00 . Because of variations in the mass flow rate, there was a particular value of external electrical source energy consumption for each thermal plasma generator scenario. Both assumptions and measured energy usage were essential in ASPEN PLUS' mEPJ model input. Model findings were a molar fraction of syngas composition, syngas mass flow rate, syngas density, $\mathrm{CO}_{2}$ emission, reactor, and syngas' thermal distribution.
The equations below were used to estimate the performance parameter, which was calculated syngas yield $\left(\mathrm{Nm}^{3} / \mathrm{kg}\right), \mathrm{CH}_{4}$ rate $(\mathrm{kg} / \mathrm{s})$, LHV syngas $\left(\mathrm{MJ} / \mathrm{Nm}^{3}\right)$, carbon conversion efficiency (Xc,-\%), cold gas efficiency (CGE, -\%), energy potential (EP,$\mathrm{MW})$ were as follows:

Rate $\mathrm{CH}_{4}=\mathrm{u}^{*} \frac{x \mathrm{CH}_{4}}{100} * \frac{\mathrm{m} \mathrm{C}}{\mathrm{m} \mathrm{CH}_{4}} * \delta \mathrm{CH}_{4}$

Gas yield $\left(\frac{\mathrm{Nm}^{3}}{\mathrm{~kg}}\right)=\frac{\text { syngas production rate }\left(\mathrm{N} \frac{\mathrm{m}^{3}}{\mathrm{~h}}\right)}{\text { coal consumption rate }\left(\frac{\mathrm{kg}}{\mathrm{h}}\right)}$

$L H V_{\text {Syngas }}=H H V-10.79 \gamma_{\mathrm{H}_{2}}+12.62 \gamma_{C O}+35.81 \gamma_{\mathrm{CH}_{4}}$

$\mathrm{XC}=\left[\frac{\mathrm{LHV}_{\text {syngas }}{ }^{*}(\mathrm{CO} \%+\mathrm{CO} 2 \%+\mathrm{CH} 4 \%+\mathrm{COS} \%)}{\mathrm{LHV}_{\text {feedstock }}{ }^{*} \mathrm{C} \%}\right] * 100 \%$

Where $\mathrm{\gamma CO}_{2}, \mathrm{CO}, \mathrm{CH}_{4}$, and $\mathrm{C}$ are product percentages of $\mathrm{CO}_{2}, \mathrm{CH}_{4}$, and $\mathrm{CO}$ on the syngas and carbon content from MSW. $\mathrm{LHV}_{\text {syngas }}$ and $\mathrm{LHV}_{\text {feedstock }}$ were LHV for syngas and coal.

$\mathrm{CGE}=\frac{\mathrm{LHV}_{\text {syngas }} \mathrm{F}_{\text {syngas }}}{\mathrm{LHV}_{\text {coal }} \dot{m}_{\text {coal }}+P_{\text {plasma }}} * 100 \%$

Where $F_{\text {syngas }}$ was the volumetric flow rate of syngas, $m_{\text {coal }}$ was the mass flow rate of coal, $P_{\text {plasma }}$ is energy consumption for thermal plasma generator to generate heat to reach the desired plasma temperature.

Electric Energy Potential $(\mathrm{EEP})=$

$\mathrm{Y}_{\text {syngas }} * \frac{x \mathrm{H}_{2}}{100} / \mathrm{N}^{*} \delta \mathrm{H}_{2}{ }^{*} \mathrm{GGE} / \mathrm{CF}$.

Nett Energy Potensial $=\mathrm{EEP}-\left(\mathrm{P}_{\text {Sep }}+\right.$

$\left.\mathrm{P}_{\text {Plasma }}+\mathrm{P}_{\text {Steam }}+\mathrm{P}_{\text {Oxygen }}\right)$......

Table 5. Coal Gasification reactions

\begin{tabular}{|c|c|c|c|}
\hline Reaction & Reaction type & Reaction & $\Delta \mathrm{H}(\mathrm{kJ} / \mathrm{mol})$ \\
\hline \multicolumn{4}{|c|}{ Oxidation Reaction } \\
\hline R1 & Carbon Combustion & $\mathrm{C}+\mathrm{O}_{2} \rightarrow \mathrm{CO}_{2}$ & -394 \\
\hline \multicolumn{4}{|c|}{ Carbon Reaction } \\
\hline $\mathbf{R} 2$ & Baoudouard & $\mathrm{C}+\mathrm{CO}_{2} \leftrightarrow 2 \mathrm{CO}$ & +172 \\
\hline R3 & Water-gas or steam & $\mathrm{C}+\mathrm{H}_{2} \mathrm{O} \leftrightarrow \mathrm{CO}+\mathrm{H}_{2}$ & +131 \\
\hline \multicolumn{4}{|c|}{ Methanation Reaction } \\
\hline R4 & Methanation of Carbon & $\mathrm{C}+2 \mathrm{H}_{2} \rightarrow \mathrm{CH}_{4}$ & -74 \\
\hline \multicolumn{4}{|c|}{ Shift Reaction } \\
\hline R5 & Water Gas Shift & $\mathrm{CO}+\mathrm{H}_{2} \mathrm{O} \leftrightarrow \mathrm{CO}_{2}+\mathrm{H}_{2}$ & -41.2 \\
\hline
\end{tabular}


Where $\gamma_{\text {syngas }}$ is the syngas yield, $x_{2}$ is the molar fraction of $\mathrm{H}_{2}, \mathrm{~N}$ is the normalized factor, $\delta \mathrm{H}_{2}$ is the density of $\mathrm{H}_{2}$. GGE/CF is the conversion factor for energy potential. $P_{\text {Sep }}$ is the energy consumption for $\mathrm{H}_{2}$ Purification Plant, $P_{\text {steam }}$ is the energy consumption for Steam Generator, $P_{\text {oxygen }}$ is the energy consumption for Oxygen Generator.

Once the performance parameter is summarized, those data are analyzed by comparing each scenario's parameters on each gasifying agent-data analyzing for energy recovery, material recovery, and minimizing environmental impact.

\section{RESULT AND DISCUSSION}

The effect of gasifying agent ratios on the feedstock of the syngas structure, temperature distribution, energy potential, overall quality, and polluting gas emission was recorded in this analysis.

\section{Effect of Gasifying Agent on the Syngas Composition}

There are 2 (two) main products: Hydrogen and Carbon Monoxide since only those two can be utilized as raw materials of energy and chemical industry. The other significant syngas fraction of water was considered as the byproduct of gasification and can be utilized for the steam generator water input, which was not the focus of this research.

The variation of the gasifying agent mass flow ratio to the hydrogen molar fraction's coal mass flow indicates a decreasing PS trend. Still, an increasing trend occurred for the SO. The R-squared value on the chart shows that the R2 $=0.2589$ and on SO trend line on the $\mathrm{PS}$ trend line have the $\mathrm{R}^{2}=0.9879$. Among 5 (five) ratios on $\mathrm{PS}$, the first ratio of 0.2 was unfitted to the regression line, as seen in Figure 5. The Hydrogen molar fraction shows that PS has a better value than SO, which the highest molar fraction of PS was approximately 3 (three) times higher than SO, as can be seen in Figure 5.

The variation of the gasifying agent mass flow ratio to the coal mass flow for the carbon monoxide molar fraction shows that a decreasing trend occurred on PS and SO. The R-Squared value on the PS trendline = 0.9213 and the SO trendline $=0.4165$. On $\mathrm{SO}$, the ratio of 0.4 and 0.6 did not fit into the regression line. Both $\mathrm{PS}$ and $\mathrm{SO}$ trendlines had the highest carbon monoxide value on the ratio of 0.4 . The carbon monoxide molar fraction shows that PS had a better value than SO, which the highest molar fraction of PS was approximately 2 (two) times higher than $\mathrm{SO}$, as can be seen in Figure 6.

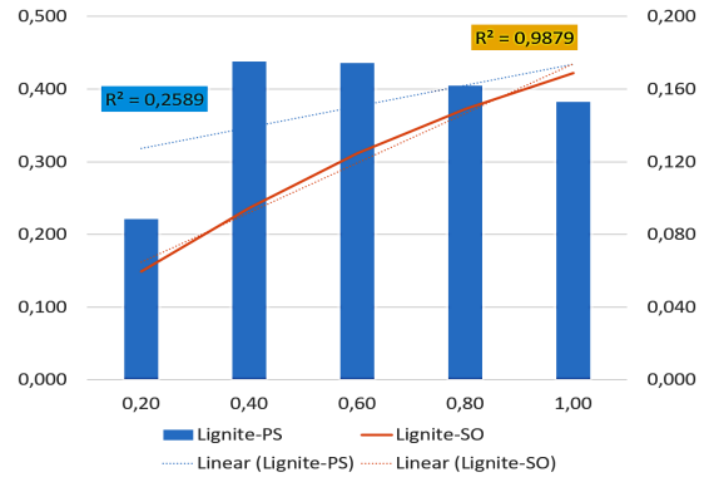

Figure $5 . \mathrm{H}_{2}$ molar fraction versus gasifying agent ratio

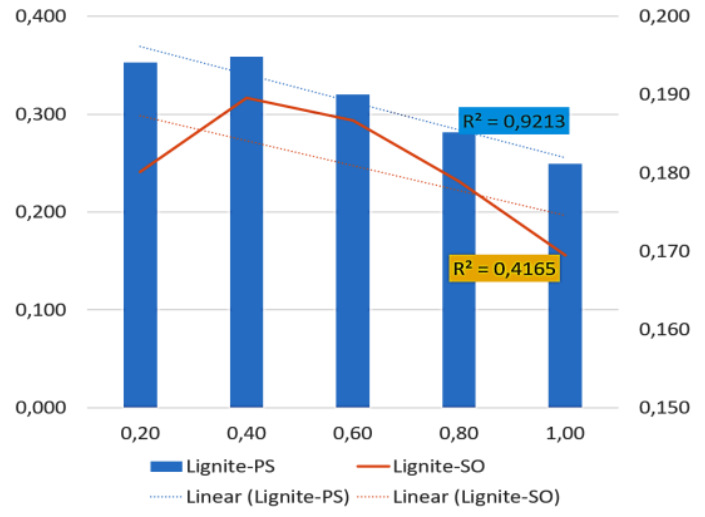

Figure 6. CO molar fraction versus gasifying agent ratio

Using the PS as the gasifying agent has the advantage of enriching the molar fraction of hydrogen in the syngas since it can introduce more $\mathrm{H}$ elements from the steam into the syngas composition (Favas, Monteiro and Rouboa, 2017). Oxygen's introduction to the reactor reduces the $\mathrm{H}$ element since it drives combustion and consumes more energy (Mapamba, Conradie and Fick, 2016). 


\section{Effect of Gasifying Agent on the Temperature Distribution}

There are 2 (two) concerning areas to monitor temperature variation: the hottest parts of the reactor, which was called PGZHTR Temp, where the gasifying agent contact with the coal, and the exit of syngas, which was the nozzle parts of the syngas exit's gasifying reactor.

The variation of the gasifying agent mass flow ratio to the coal mass flow for the PGZ-HTR temperature indicated that an increasing trend occurred for the PS and SO. The PS trendline steepens from $1722{ }^{\circ} \mathrm{C}$ to $3114^{\circ} \mathrm{C}$, and the SO trendline slops from $3226^{\circ} \mathrm{C}$ into $3336^{\circ} \mathrm{C}$. The R-squared the PS trendline $=$ 0.9852 , and the SO trendline $=0.796$. The temperature distribution on PGZ-HTR of PS as the gasifying agent had better values compared to the SO. The temperature distribution on the PGZ-HTR area showed that PS had a better value than SO. The lowest temperature of PS was approximately half of SO's temperature on the first ratio, as shown in Figure 7. The lower the temperature distribution, the easier to fabricate the gasification reactor.

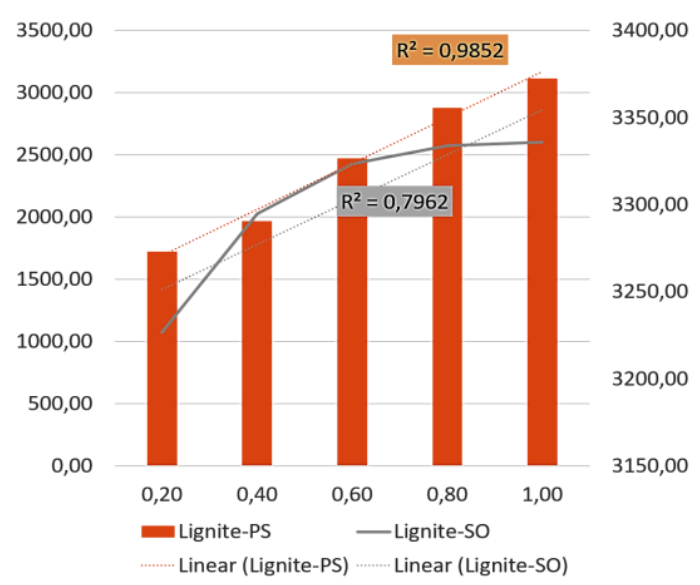

Figure 7. PGZ-HTR temp $\left({ }^{\circ} \mathrm{C}\right)$ versus gasifying agent ratio

The gasifying-agent mass flow ratio variation to the coal mass flow for the nozzle of syngas exit temperature indicates an increasing PS and SO trend. The PS was steepened from $978^{\circ} \mathrm{C}$ to $1092^{\circ} \mathrm{C}$, while the SO was sloping from $1097^{\circ} \mathrm{C}$ to $1127^{\circ} \mathrm{C}$. The R-squared on the PS trendline $=0.9798$ and the SO trendline $=0.9901$. The temperature distribution on SO's syngas exit as the gasifying agent had better values than the PS, as shown in Figure 8. The lesser the temperature distribution, the easier to fabricate the syngas treatment.

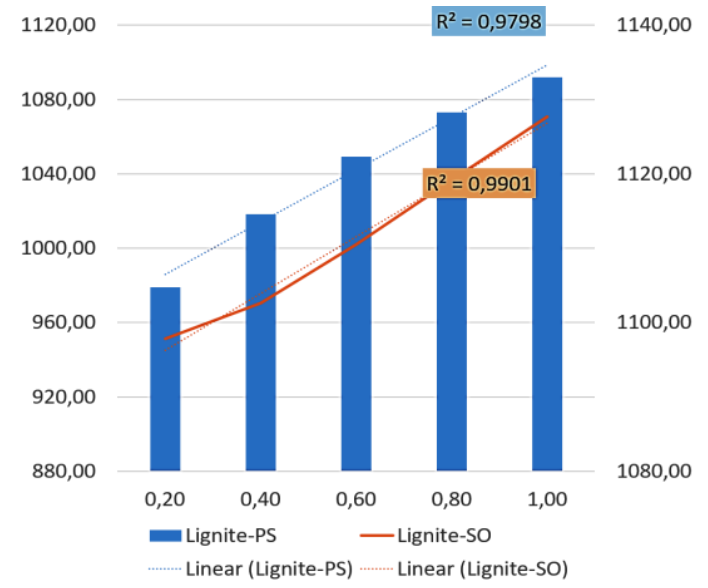

Figure 8. Syngas temp $\left({ }^{\circ} \mathrm{C}\right)$ versus gasifying agent ratio

\section{Effect of Gasifying Agent on Energy Potential}

There are 2 (two) kinds of energy that need to be analyzed and prioritized since the research's primary concern was to develop new energy potential from low-rank coal. The first was gross energy potential, where the hydrogen fraction of syngas was converted into gasoline gallon equivalent (GGE) and converted into electricity equivalent. Those equivalent constants were considered since the NIST (national institute of standard and technology) defines its value as equal to 5,660 pounds of natural gas. It is difficult to compare gasoline costs with other fuels if they are purchased in different units. One GGE of electricity has the same energy content as one gallon of gasoline ( $\mathrm{UCl}$ Physics, 2014). Using GGE as the comparison of fuels for an internal combustion engine (ICE) is an integral part of this research to estimate the energy potential.

The second was the net energy potential, the gross energy potential minus the energy intake of hydrogen purification, the plasma torch, the oxygen generator, and the steam generator. Hydrogen energy potential was estimated from its chemical energy source. 
The variation of the gasifying agent mass flow ratio to the gross energy potential coal mass flow indicates an increasing PS and SO trend. The R-squared value on the chart shows that on the PS trendline, it had the $\mathrm{R}^{2}$ $=0.3275$. On the SO trendline, it had the $\mathrm{R}^{2}$ $=0.9978$. Among 5 (five) ratios on PS, the first ratio of 0.2 was unfitted to the regression line, as seen in Figure 9.

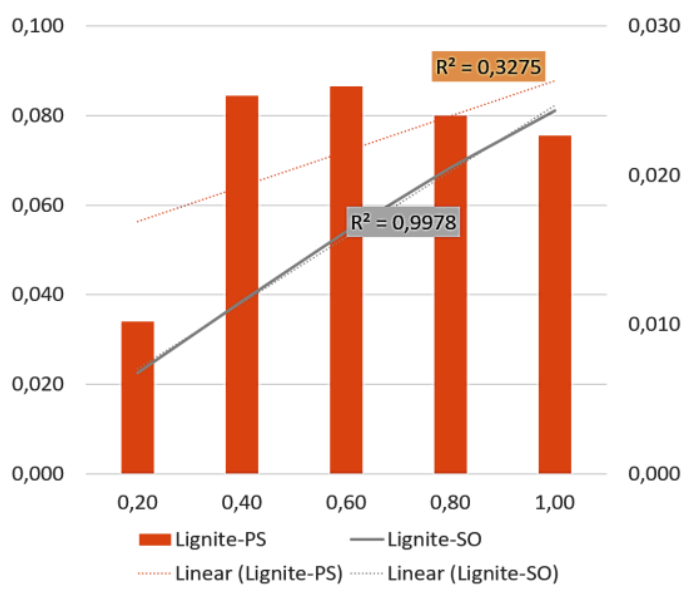

Figure 9. The gross energy potential versus gasifying agent ratio

The gross energy potential shows that PS had a better value than $\mathrm{SO}$, which the highest molar fraction of PS was approximately 7 (seven) times higher than SO, on the ratio of 0.4 , as can be seen in Figure 9.

The variation of the gasifying agent mass flow ratio to the Net Energy Potential coal mass flow indicates an increasing trend for the PS and SO. The R-square value of 0.0445 on the PS trendline and 0.9468 on the SO trendline. Among 5 (five) ratios on PS, on the first ratio: 0.2 was the unfitted to the regression line, as seen in Figure 10. The net energy potential shows that the PS had a better value than the SO, which the highest value of the PS was approximately 17 times higher than the SO, on the ratio of 0.4 , as can be seen in Figure 10.

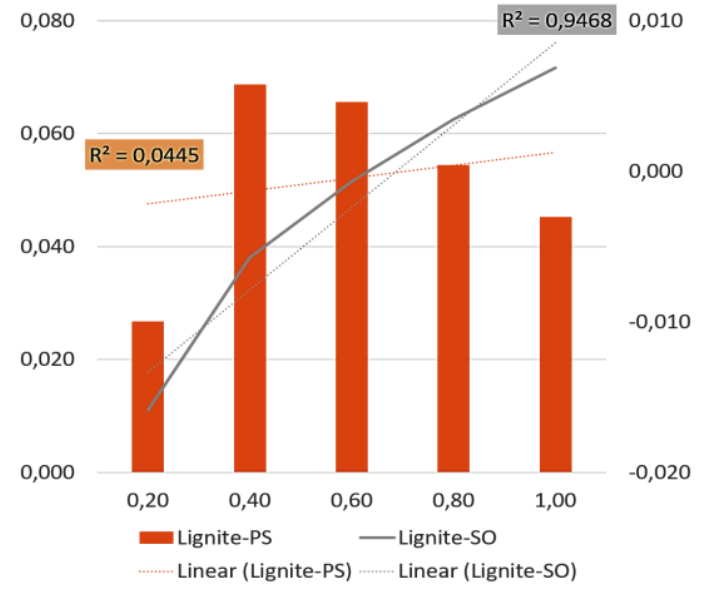

Figure 10. Net Energy Potential versus gasifying agent ratio

\section{Effect of Gasifying Agent on the Overall Efficiency}

There are 2 (two) forms of efficiency that need to be evaluated and prioritized. The research's primary concern was to estimate the new energy potential from low-rank coal and ensure that it was commercially viable to ensure that the technology achieved the anticipated efficiency. The first was cold gas efficiency, defined as the ratio of syngas LHV to coal/feedstock LHV and plasma generator energy consumption (Pagano et al., 2019). The second was carbon conversion efficiency, defined as the percentage of total carbon in the syngas to the percentage of total carbon in feedstock (coal) (Favas, Monteiro and Rouboa, 2017). These two indices are critical to measuring plasma gasification performance (Mapamba, Conradie and Fick, 2016).

The variation of the gasifying agent mass flow ratio to the coal mass flow for the cold gas efficiency showed that a decreasing trend occurs on PS, and an increasing trend occurs on SO. The R-Squared value on the PS trendline $=0.325$, and the SO trendline $=$ 0.9903. With the highest CGE value on the ratio of $0.4,37.71 \%$, and SO trendline, PS trendline had the highest CGE value on the ratio of 1.00 , which was $23.17 \%$. The CGE value showed that $P S$ had a better value than SO, which the highest molar fraction of PS was approximately 2 (two) times higher than SO, as can be seen in Figure 11. 


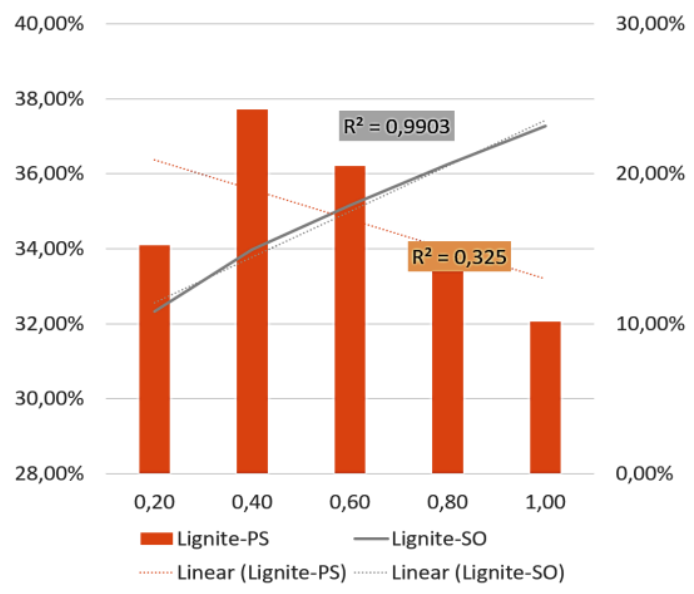

Figure 11. Cold gas efficiency versus gasifying agent ratio

The gasifying agent mass flow ratio variation to the coal mass flow for the carbon conversion efficiency showed that a decreasing trend occurred on PS. An increasing trend occurred on SO. The RSquared value on the PS trendline $=0.8482$, and the SO trendline $=0.308$. The carbon conversion was limited by the methane $\left(\mathrm{CH}_{4}\right)$ reforming (Mapamba, Conradie and Fick, 2016). PS trendline, with the highest $X_{c}$ value on the ratio of 0.1 , which was $4.75 \%$, and SO trendline had the highest $\mathrm{Xc}$ value on the ratio of 0.6 , which was $0.61 \%$, as shown in Figure 12.

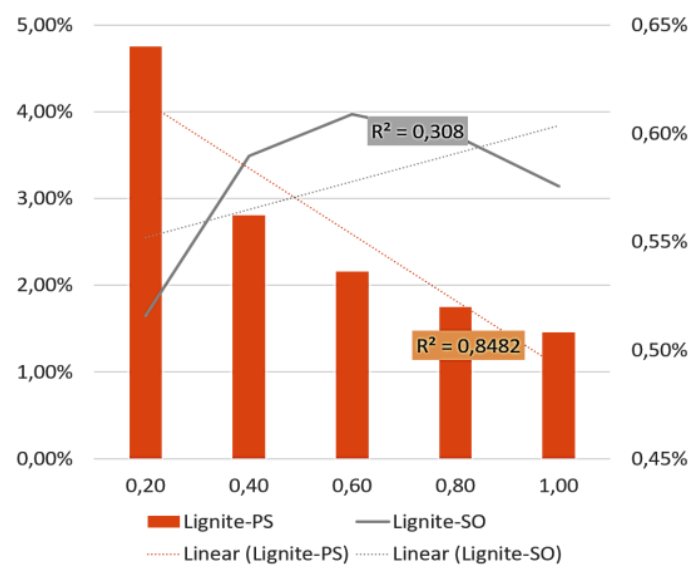

Figure 12. Carbon conversion efficiency versus gasifying agent ratio

\section{Effect of Gasifying Agent on GHG Emission}

Gasification-based plasma for power generation results in significantly lower pollutant emissions than traditional gasification, which can be attributed to the fundamental distinction between thermal and conventional plasma. Oxygen is usually supplied to the gasifier and sufficiently combusts in conventional gasification, providing heat to gasify the feedstock. Still, in plasma thermal, the heat is provided through the thermal plasma, delivered by the gasifying agent to react with the feedstock. Although plasma gasification is not negative emission technology (NETs), its contribution by emitting very low carbon dioxide to the atmosphere is considered a friendly technology to the environment.

The variation of the gasifying agent mass flow ratio to the coal mass flow for the $\mathrm{CO}_{2}$ emission showed that a decreasing trend occurs on PS, and an increasing trend occurs on SO. The R-Squared value on the PS trendline $=0.5929$, and the SO trendline $=$ 0.9903. With the lowest $\mathrm{CO}_{2}$ emission value on the ratio of 0.6 , which was $5.98 \mathrm{E}-05 \mathrm{~kg} / \mathrm{s}$ and $\mathrm{SO}$ trendline, PS trendline has the lowest $\mathrm{CO}_{2}$ emission value on the ratio of 0.20 7.9.E$04 \mathrm{~kg} / \mathrm{s}$. The $\mathrm{CO}_{2}$ emission value showed that PS had a better value than SO, which the lowest $\mathrm{CO}_{2}$ emission value of $\mathrm{PS}$ was approximately 10 (ten) times lower than SO, as can be seen in Figure 13.

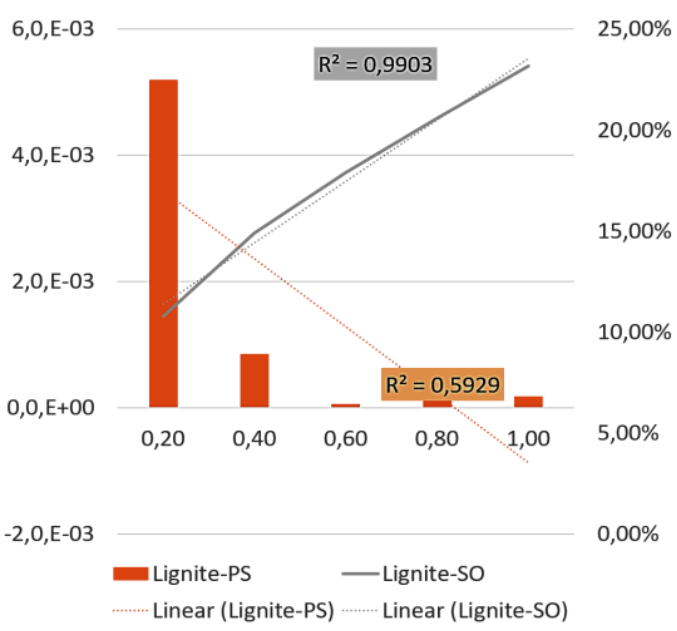

Figure 13. $\mathrm{CO}_{2}$ emission versus gasifying agent ratio 
The variation of the gasifying agent mass flow ratio to the coal mass flow for the $\mathrm{CH}_{4}$ emission showed that a decreasing trend occurred on PS, and a flat trend occurred on $\mathrm{SO}$ approximately to 0 . The R-Squared value on the PS trendline $=0.624$, and the PS trendline had the lowest $\mathrm{CH}_{4}$ emission value on the ratio of 1.0 , which was $2.48 \mathrm{E}-15 \mathrm{~kg} / \mathrm{s}$. The $\mathrm{CH}_{4}$ emission value showed that PS has a worse value than SO but can be neglected since the difference was very few, as shown in Figure 14.

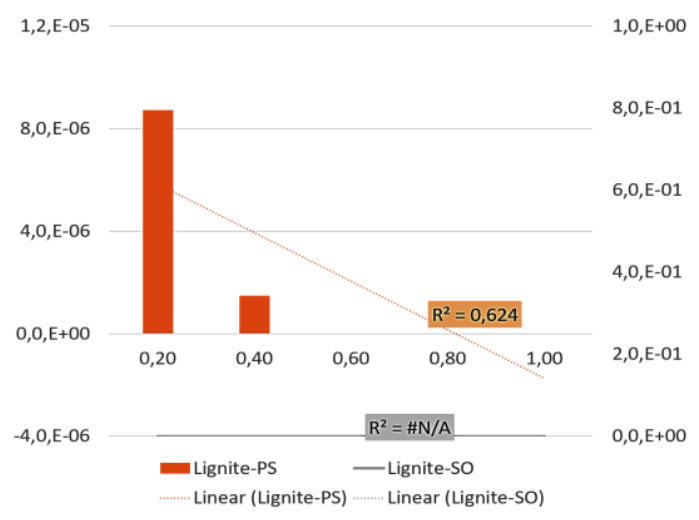

Figure 14. $\mathrm{CH}_{4}$ emission versus gasifying agent ratio

In overall trends, the use of PS was considered better than SO. It can be found that the PGZ-HTR temperature rosed in line with the power consumption for Plasma Torch boosts the gasification reactions, resulting in the rosed of $\mathrm{H}_{2}$ and $\mathrm{CO}$ concentration in 0.4 ratios of GA to feedstock. Its percentage then falls, which was a little contrary to the literature (Mapamba, Conradie and Fick, 2016). The gasification temperature rosed with the power load rosed and boosted the gasification reactions, resulting in the $\mathrm{CO}$ concentration rosed in the syngas product. It was also found that $\mathrm{H}_{2}$ concentration felled with the rosed in power loads. It can be explained by the reactor's side reaction since, during the high temperature, the reverse water-gas shift (R5) occurred.

Moreover, the concentration of $\mathrm{CH}_{4}$ fell with the power loads rosed, which was probably due to a side reaction's presence: the reverse methane reforming (R4) occurred. The decrease in $\mathrm{H}_{2}$ and $\mathrm{CH}_{4}$ concentration resulted in a decrease in LHV, which was in line with the literature (Maneerung et al., 2018).

\section{CONCLUSIONS}

This research has been carried out to understand the impact of the different gasifying agents within Plasma Gasification for Low-Rank Coal better utilization.

PS as the gasifying agent was significantly better than $\mathrm{SO}$ in terms of such as having a higher $\mathrm{H}_{2}$ to coal ratio of 0.4 has shown $43.76 \%$, higher CGE to coal ratio of 0.4 has shown $37.71 \%$, and carbon conversion to coal ratio of 0.2 has shown $4.75 \%$. PS to coal ratio of 0.6 has a gross energy potential of $86.5 \mathrm{~kW}$. Using PS is significantly better than a mixture of $\mathrm{SO}$ as the gasifying agent since it needs to have a greater SO flow rate to have SO to coal ratio of 1.00 . But the drawback of the PS is having higher $\mathrm{CO}_{2}$ and $\mathrm{CH}_{4}$ emissions compared to SO.

Further studies can be carried out by including the hydrogen purification process and the use of syngas $\mathrm{CO}$ converted to $\mathrm{H}_{2}$ with water-gas shift technology.

\section{ACKNOWLEDGMENT}

I thank the following individuals for their expertise and assistance throughout all aspects of our study and for their help in writing the manuscript as follow:

- Ir. Sunaryo, M.Pd., M.T. (University of Sains Al Qur'an Wonosobo) for providing discussion related to the thermal plasma torch.

- Puji Basuki, S.T., M.T., (University of Pandanaran Semarang) for providing discussion related to the thermal plasma reactor.

\section{REFERENCES}

Air Liquide (2017) CO cold box - Syngas separation and purification, Air Liquide Engineering \& Construction.

Available at: https://www.engineeringairliquide.com/co-cold-box-syngasseparation-and-purification (Accessed: 12 December 2020).

BLU tekMIRA (2019) Tekmira tawarkan teknologi gasifikasi batubara bawah permukaan untuk tekan biaya dan dampak lingkungan, www.tekmira.esdm.go.id. Available at: https://www.tekmira.esdm.go.id/index.ph 
p/berita1/tekmira-tawarkan-teknologigasifikasi-batubara-bawah-permukaanuntuk-tekan-biaya-dan-dampaklingkungan (Accessed: 12 December 2020).

Enersol Technologies (2019) EnerSol PEGS ® Gasification systems, www.enersoltech.com. Available at: https://www.enersoltech.com/pegs.htm (Accessed: 12 December 2020).

Favas, J., Monteiro, E. and Rouboa, A. (2017) 'Hydrogen production using plasma gasification with steam injection', International Journal of Hydrogen Energy, 42(16), pp. 10997-11005. doi: 10.1016/j.ijhydene.2017.03.109.

Georgiev, I. B. and Mihailov, B. I. (1992) 'Some general conclusions from the results of studies on solid fuel steam plasma gasification', Fuel, 71(8), pp. 895-901. doi: 10.1016/0016-2361(92)90239-K.

Gil, J., Corella, J., Aznar, M. P. and Caballero, M. A. (1999) 'Biomass gasification in atmospheric and bubbling fluidized bed: Effect of the type of gasifying agent on the product distribution', Biomass and Bioenergy, 17(5), pp. 389-403. doi: 10.1016/S0961-9534(99)00055-0.

Guo, X., Tang, Y., Wang, Y., Eble, C. F., Finkelman, R. B., Huan, B. and Pan, $X$. (2021) 'Potential utilization of coal gasification residues from entrained-flow gasification plants based on rare earth geochemical characteristics', Journal of Cleaner Production, 280, p. 124329. doi: 10.1016/j.jclepro.2020.124329.

Maneerung, T., Li, X., Li, C., Dai, Y. and Wang, C.H. (2018) 'Integrated downdraft gasification with power generation system and gasification bottom ash reutilization for clean waste-to-energy and resource recovery system', Journal of Cleaner Production. Elsevier Ltd, 188, pp. 69-79. doi: 10.1016/j.jclepro.2018.03.287.

Mapamba, L. S., Conradie, F. H. and Fick, J. I. J. (2016) 'Technology assessment of plasma arc reforming for greenhouse gas mitigation: a simulation study applied to a coal to liquids process', Journal of Cleaner Production. Elsevier Ltd, 112, pp. 10971105. doi: 10.1016/j.jclepro.2015.07.104.

Minutillo, M., Perna, A. and Di Bona, D. (2009) 'Modelling and performance analysis of an integrated plasma gasification combined cycle (IPGCC) power plant', Energy
Conversion and Management, 50(11), pp. 2837-2842.

doi: 10.1016/j.enconman.2009.07.002.

Mishra, A., Gautam, S. and Sharma, T. (2018) 'Effect of operating parameters on coal gasification', International Journal of Coal Science \& Technology. Springer Singapore, 5(2), pp. 113-125. doi: 10.1007/s40789-018-0196-3.

Nayak, R. and Mewada, R. K. (2011) 'Simulation of coal gasification process using ASPEN PLUS', in International Conference on Current Trends in Technology, "NUiCONE - 2011". Gujarat, India: Nirma University of Science and Technology, p. 382481.

Nikoo, M. B. and Mahinpey, N. (2008) 'Simulation of biomass gasification in fluidized bed reactor using ASPEN PLUS', Biomass and Bioenergy, 32(12), pp. 1245-1254. doi: 10.1016/j.biombioe.2008.02.020.

Nursanto, E. and Ilcham, A. (2018) 'Characteristic of low rank coal from Warukin Formation, South Kalimantan and their implication for coal liquefaction', IOP Conference Series: Earth and Environmental Science, 212(1), p. 012027. doi: 10.1088/1755-1315/212/1/012027.

Pagano, G., Thomas, P. J., Di Nunzio, A. and Trifuoggi, M. (2019) 'Human exposures to rare earth elements: Present knowledge and research prospects', Environmental Research. Elsevier Inc., 171(December 2018), pp. 493-500. doi: 10.1016/j.envres.2019.02.004.

Pourali, M. (2010) 'Application of plasma gasification technology in waste to energy-Challenges and opportunities', IEEE Transactions on Sustainable Energy, 1(3), pp. 125-130. doi: 10.1109/TSTE.2010.2061242.

Samal, S. (2017) 'Thermal plasma technology: The prospective future in material processing', Journal of Cleaner Production. Elsevier Ltd, 142, pp. 31313150. doi: 10.1016/j.jclepro.2016.10.154.

Sesotyo, P. A., Nur, M. and Muraza, O. (2020) 'Simulation of syngas production through plasma gasification from Indonesia's lowgrade coal as a new energy', in Brawijaya International Conference on Multidisciplinary Sciences and Technology 2020. Malang, Indonesia, p. EN-1207-302. 
INDONESIAN MINING JOURNAL Vol. 24, No. 1, April $2021: 57$ - 70

Sesotyo, P. A., Nur, M. and Suseno, J. E. (2019) 'Plasma gasification with municipal solid waste as a method of energy self sustained for better urban built environment: Modeling and simulation', IOP Conference Series: Earth and Environmental Science, 396(1), p. 012002 . doi: 10.1088/1755 1315/396/1/012002.

Sihite, T. (2012) 'Low rank coal utilization in Indonesia', in Clean Coal Day in Japan International Symposium. Tokyo: JCoal, pp. 1-21.

Sudiro, M. and Bertucco, A. (2009) 'Production of synthetic gasoline and diesel fuel by alternative processes using natural gas and coal: Process simulation and optimization', Energy. Elsevier Ltd, 34(12), pp. 2206-2214.

doi: 10.1016/j.energy.2008.12.009.
Tobergte, D. R. and Curtis, S. (2013) 'Summary for policymakers', in Intergovernmental Panel on Climate Change (ed.) Climate Change 2013 - The Physical Science Basis. Cambridge: Cambridge University Press, pp. 1-30. doi: 10.1017/CBO9781107415324.004.

UCI Physics (2014) 'Gasoline gallon equivalent', 2014.

United Nation (2018) Energy statistics yearbook 2018. New York: United Nations Publications.

Yoon, S. J. and Goo Lee, J. (2012) 'Syngas production from coal through microwave plasma gasification: Influence of oxygen, steam, and coal particle size', Energy \& Fuels, 26(1), pp. 524-529. doi: $10.1021 /$ ef2013584. 